DOI 10.15290/cnisk.2020.01.08.02

AGNIESZKA SZUDAREK

https://orcid.org/0000-0002-6851-9808

Uniwersytet Szczeciński

\title{
O potrzebie transnarodowego spojrzenia na „kwestię kobiecą” pod zaborem pruskim na przełomie XIX i XX wieku ${ }^{1}$
}

\begin{abstract}
Streszczenie
W dotychczasowych badaniach nad „kwestia kobieca” pod zaborem pruskim dominowało podejście narodowe. Polki ukazywane były jako strażniczki tożsamości narodowej, których nie interesowała walka o prawa kobiet. Aktywność Niemek nie była dotąd przedmiotem badań i informacje o niej ograniczały się do wskazania ich nacjonalistycznego zaangażowania. Ukształtował się więc obraz kobiet obu narodowości żyjących w sąsiedztwie, ale w dwóch wrogich wobec siebie społeczeństwach. Nowsze wyniki badań ujawniły jednak przypadki współpracy. Ich analiza wymaga przyjęcia odmiennej perspektywy analitycznej, a więc odejścia od paradygmatu konfliktu i wykorzystania możliwości, jakie daje zwrot transnarodowy w badaniach historycznych. Historia transnarodowa zajmuje się wszystkim, co przepływa i krzyżuje się ponad państwami i społeczeństwami, a więc także koncepcjami, które aktywizowały kobiety do działania. Pozwala więc szukać wspólnych przestrzeni Polek i Niemek pod zaborem pruskim, które mogły powstawać w ramach pewnej wspólnoty wartości związanej z dążeniem do rozwiąania „kwestii kobiecej”.
\end{abstract}

1 Publikacja przygotowana/finansowana w ramach programu Ministra Nauki i Szkolnictwa Wyższego pod nazwa DIALOG w latach 2019-2021. Jest wynikiem udziału w projekcie badawczym pt. „Ośrodek badań historii kobiet”, nr 0016/DLG/2019/10. 
Słowa kluczowe: historia transnarodowa, zabór pruski, stosunki polsko-niemieckie, historia kobiet

\title{
ON THE NEED TO USE TRANSNATIONAL VIEW ON THE 'WOMEN QUESTION' UNDER THE PRUSSIAN PARTITION AT THE TURN OF THE 19TH AND 20TH CENTURIES
}

\begin{abstract}
So far the research on the "woman question" under the Prussian partition has been dominated by the national paradigm. Through it Polish women were presented as female guardians of the national identity who were not interested in the battle for women's rights. On the other hand, there has been no research on the engagement of German women and information about it was limited to their commitment to nationalism. Therefore an image emerged in which those women were depicted as coming from two neighbouring but hostile nationalities and societies. However, the most recent research revealed that some cases of cooperation existed. In order to analyse them, however, we need to use another analytical perspective: abandon the paradigm of conflict and instead take the opportunities brought about by the transnational turn in historical research. Transnational history deals with everything that floats and meets beyond the borders of states and societies, and that also includes the concepts that mobilised women to get involved. Therefore it allows to discover common ground for Polish and German women under the Prussian partition that might have laid foundations for a community of shared values to address the "woman question".
\end{abstract}

Keywords: transnational history, Prussian Poland, Polish-German relations, women's history

\section{Wstęp}

W ostatnich latach w badaniach nad relacjami polsko-niemieckimi pod zaborem pruskim można obserwować nowe podejście teoretyczne, które przełamuje dominujacy we wcześniejszej historiografii paradygmat narodowy eksponujaccy napięcia i antagonizmy między Polakami a Niemcami w XIX i XX w. Oznacza to reinterpretację wzajemnych relacji i oddziaływań, w tym także poszukiwanie „miejsc wspólnych”, a więc tego, co łączyło obie narodowości w kontekście przemian społecznych, gospodarczych czy 
życia religijnego ${ }^{2}$. Oczywiście nie oznacza to kwestionowania odmiennych interesów obu narodów oraz wynikajacych stąd konfliktów, zwłaszcza po zmianie kursu w pruskiej tzw. Polenpolitik, czyli odwrotu w drugiej połowie lat 80. XIX w. od „asymilacyjnego Kulturkampfu” i przejścia $z$ „walki o dusze” do „walki o ziemię”, która to miała zakończyć się powstaniem homogenicznego narodu niemieckiego. Podejście to stanowi raczej przejaw dażenia do skonstruowania pełniejszego obrazu życia społecznego, uchwycenia jego wielobarwności, ale przede wszystkim wyzbycia się ocen i interpretacji uwikłanych w polityczne koniunktury, co było charakterystyczne zarówno dla polskiej myśli zachodniej, jak i niemieckiej Ostforschung ${ }^{3}$. Wskazana perspektywa badawcza zaowocowała już publikacjami, wśród których wyróżnia się seria prac na temat procesów akulturacji/asymilacji na pograniczu polsko-niemieckim w XIX i XX w., wydana pod redakcja Roberta Traby ${ }^{4}$. Oprócz interesujących studiów szczegółowych zawiera ona także rozważania teoretyczne redaktora naukowego serii przybliżające czytelnikowi m.in. historię wzajemnych oddziaływań (Beziehungsgeschichte) Klausa Zernacka oraz wskazujące na przydatność analityczna filozoficzno-socjologicznej kategorii tzw. świata przeżywanego (Lebenswelt) ${ }^{5}$. Prace te upowszechniaja także aparat pojęciowy nawiazujący do dorobku socjologii, antropologii kultury i etnologii, który ze względu na to, że nie jest nieobciążony wartościującymi konotacjami widocznymi chociażby w sformułowaniach „germanizacja”, „polonizacja” czy „wynaradawianie”, otwiera drogę do badania kontaktów między Polakami i Niemcami według tych

2 Zob. m.in. Mark Tilse, Transnationalism in the Prussian East. From National Conflict to Synthesis 1871-1914, (Basingstoke: Palgrave Macmillan, 2011); Szczepan Wierzchosławski, Orzeł czarny i orzeł biały. Problemy modernizacji społeczeństwa polskiego prowincji Prusy Zachodnie w XIX i na poczatku XX stulecia, (Olsztyn: Littera, 2011).

3 Robert Traba, „Procesy akulturacji/asymilacji w perspektywie badań historycznych. Przypadek pogranicza polsko-niemieckiego w XIX-XX wieku”, w: Robert Traba (red.), Akulturacja/asymilacja na pograniczach kulturowych Europy Środkowo-Wschodniej w XIX i XX wieku, t. 2: Sasiedztwo polsko-niemieckie, (Warszawa: Oficyna Wydawniczo-poligraficzna „Konika”, 2012), 10-12; Rex Rexheuser, „Wprowadzenie”, w: Witold Molik, Robert Traba (red.), Procesy akulturacji/asymilacji na pograniczu polsko-niemieckim w XIX i XX wieku, (Poznań: Instytut Historii UAM, 1999), 7-8.

4 Robert Traba (red.), Akulturacja/asymilacja na pograniczach kulturowych Europy Środkowo-Wschodniej w XIX i XX wieku, t. 1: Stereotypy i pamięć, (Warszawa: Oficyna Wydawniczo-poligraficzna „Konika”, 2009); idem (red.), Akulturacja/asymilacja na pograniczach kulturowych Europy Środkowo-Wschodniej w XIX i XX wieku, t. 2; Witold Molik, Robert Traba (red.) Procesy akulturacji/asymilacji na pograniczu polsko niemieckim $w$ XIX $i$ XX wieku, (Poznań: Instytut Historii UAM, 1999).

5 Robert Traba, „Procesy akulturacji/asymilacji”, 10-12. 
samych kryteriów oraz z szerszej perspektywy, umożliwiającej dostrzeżenie nie tylko punktów zapalnych, ale także płaszczyzn współpracy. Oznacza to więc stawianie pytań $\mathrm{m}$.in. o to, co na poziomie lokalnym ich aktywizowało i stwarzało przesłanki do współdziałania i w konsekwencji prowadziło do transferu idei czy syntezy kulturowej6.

\section{Paradygmat narodowy a „kwestia kobieca”}

\section{Przełamanie narodowo-historycznych perspektyw poznawczych} dotyczących relacji polsko-niemieckich pod zaborem pruskim nie objęło dotąd problematyki związanej $z$ „kwestią kobieca”, która stanowiła od drugiej połowy XIX w. jeden $z$ nurtów debaty na temat transformacji społeczno-ekonomicznych związanych $z$ modernizacja oraz rodzacym się społeczeństwem obywatelskim ${ }^{7}$. Badania na ten temat sa dość fragmentaryczne i asymetryczne, gdyż uwzględniają przede wszystkim sytuację i aktywność Polek ${ }^{8}$. Działalność Niemek, w tym ich zaangażowanie

6 Witold Molik, „Procesy asymilacyjne i akulturacyjne w stosunkach polsko-niemieckich w XIX i na poczatku XX wieku. Stan i postulaty badań”, w: Witold Molik, Robert Traba (red.), Procesy akulturacji/asymilacji na pograniczu, 65-67. Zob. też: idem, „Problem akulturacji na pograniczu polsko-niemieckim na przykładzie społeczeństwa polskiego w Poznańskiem w XIX i na początku XX wieku”, w: Edward Włodarczyk (red.), Pogranicze polsko-niemieckie. Przeszłość. Teraźniejszość. Przyszłość, (Szczecin: Wydawnictwo Naukowe Uniwersytetu Szczecińskiego, 2001), 43-60.

7 Robert Blobaum, „Kwestia kobieca” w Królestwie Polskim (1900-1914)”, w: Agnieszka Janiak-Jasińska, Katarzyna Sierakowska, Andrzej Szwarc (red.), Działaczki społeczne, feministki, obywatelki... Samoorganizowanie się kobiet na ziemiach polskich do 1918 roku (na tle porównawczym), (Warszawa: Neriton, 2018), 37-39.

$8 \mathrm{Z}$ nowszych prac zob.: Jarosław Urbański, Wiecowiczki, Zofia Tułodziecka i poczatki radykalnego zawodowego ruchu kobiecego w Wielkopolsce, (Poznań: Oficyna Wydawnicza Bractwo Trójki, 2018); Patrycja Kanafocka, Polki w zaborze pruskim 1793-1918. Dwie przestrzenie edukacyjne, publiczna i prywatna, (Opalenica: Wydawnictwo Opalgraf, 2014); Natali Stegmann, Die Töchter der geschlagenen Helden. „Frauenfrage“, Feminismus und Frauenbewegung in Polen 1863-1919, (Wiesbaden: Harrassowitz Verlag, 2000); Grażyna Wyder, „Towarzystwo Pomocy Naukowej dla dziewcząt polskich w Wielkim Księstwie Poznańskim w latach 1871-1918”, w: Agnieszka Janiak-Jasińska, Katarzyna Sierakowska, Andrzej Szwarc (red.), Działaczki społeczne, feministki, obywatelki. Samoorganizowanie się kobiet na ziemiach polskich do 1918 roku (na tle porównawczym), (Warszawa: Neriton, 2008), 307-321; Natali Stegmann, „Wielkopolskie wzorce kobiecej aktywności społecznej w życiu codziennym kobiet na przełomie XIX i XX wieku”, w: Anna Żarnowska, Andrzej Szwarc (red.), Kobieta i kultura życia codziennego. Wiek XIX i XX, (Warszawa: DiG, 1997), 353-369; Rudolf Jaworski, „Kilka refleksji nad dziejami Wielkopolanek w XIX i na początku XX wieku”, w: Anna Żarnowska, Andrzej Szwarc (red.), Kobieta i społeczeństwo na ziemiach polskich w XIX wieku, (Warszawa: DiG, 1995), 21-28; Agnieszka Baszko, „Towarzystwo Pomocy Naukowej dla Dziewcząt w Wielkim Księstwie Poznańskim w latach 1871-1918", Studia Historica Slavo-Germanica, t. 26, 2004/2005, 99-141. 
w przełamywanie wykluczenia kobiet $z$ szeroko pojętej sfery publicznej, mimo wciąż niesłabnącego zainteresowania zarówno women, jak i gender studies, nie została dotąd zauważona i to także przez obcą historiografię.

Brak całościowego, ponadnarodowego ujęcia „kwestii kobiecej” na ziemiach zaboru pruskiego powoduje, że w literaturze przedmiotu dominuje obraz Polek przede wszystkim jako kobiet walczacych ze skutkami polityki germanizacyjnej rządu. Podejście to generuje wizję Polek i Niemek jako przedstawicielek dwóch odrębnych oraz wrogich wobec siebie kręgów kulturowych, co przecież nie wyczerpuje problematyki zwiazanej z codzienna koegzystencją obu narodowości. Mimo to eksponowana jest działalność patriotyczna Polek oraz nacjonalistyczne zaangażowanie Niemek, rozpatrywane zresztą w izolacji, zasadniczo bez uwzględnienia oddziaływania na siebie obu sąsiadujących narodowości ${ }^{9}$. $Z$ badań wynika, że w obliczu kolejnych decyzji władz zaborczych usuwających język polski ze szkolnictwa i życia publicznego, Polki miały w życiu rodzinnym dbać o patriotyczne wychowanie dzieci oraz stać na straży tożsamości narodowej i przywiazania do wiary katolickiej. Katolicyzm definiowano $\mathrm{w}$ tym kontekście jako polską religię narodową w opozycji do protestantyzmu, wyznania uznawanego za atrybut Niemca, chociaż w Poznańskiem nie brakowało katolików mówiących po niemiecku ${ }^{10}$. Polki, jeżeli więc wkraczały do sfery publicznej, to najczęściej albo w ramach działalności opiekuńczej, albo realizujacc program oświatowo-patriotyczny ${ }^{11}$. Za przykład organizacji pierwszego typu podaje się powstałe w $1853 \mathrm{r}$. w Poznaniu Towarzystwo Pań Miłosierdzia św. Wincentego à Paulo. Drugi typ reprezentuje natomiast założone w 1894 r. Towarzystwo Przyjaciół

\footnotetext{
9 Rudolf Jaworski, „Polish Women and the Nationality Conflict in the Province of Posen at the Turn of the Century", w: Rudolf Jaworski, Bianka Pietrow-Ennker (eds.), Women in Polish Society, (New York: Columbia University Press, 1992), 53-70; Natali Stegmann, "Je mehr Bildung, desto polnischern: Die Nationalisierung polnischer Frauen in der Provinz Posen (1870-1914)", w: Ute Grau (Hrsg.), Frauen und Nation, (Tübingen: Silberburg-Verlag, 1996), 165-177. Do nielicznych wyjątków należy Patrycja Kanafocka, która omawiając szkolnictwo dla dziewcząt, zwróciła także uwagę na placówki niemieckie. Patrycja Kanafocka, Polki w zaborze pruskim 1793-1918. Dwie przestrzenie edukacyjne, publiczna i prywatna, (Opalenica: Wydawnictwo Opalgraf, 2014), 224-225.

10 Witold Matwiejczyk, Niemieccy katolicy $w$ Poznańskiem a polityka narodowościowa rzadu pruskiego 1871-1914, (Lublin: Wydawnictwo KUL, 2009).

11 Agnieszka Baszko, „Organizowanie się kobiet polskich w Poznańskiem na przełomie XIX i XX wieku”, w: Działaczki społeczne, feministki, 292-298; Grażyna Wyder, „Działalność edukacyjna kobiet - Polek w Wielkim Księstwie Poznańskim w drugiej połowie XIX wieku jako czynnik kształtowania świadomości narodowej”, Rocznik Lubuski, t. 35, 2009, cz. 1, 85-100.
} 
Wzajemnego Pouczania się i Opieki nad Dziećmi „Warta”12. Od końca XIX w. powoływane były jednak także stowarzyszenia, których cele działania wpisywały się w umiarkowany program emancypacyjny. Należały do nich organizacje mające na celu umożliwienie dziewczętom zdobycie lepszego wykształcenia, tak jak np. założone w 1870 r. w Toruniu Towarzystwo Naukowej Pomocy dla Dziewcząt, czy też samokształceniowe dla kobiet $z$ rodzin inteligenckich, jak działająca w Poznaniu do 1895 r. Czytelnia dla Kobiet. Duże znaczenie miały także stowarzyszenia samopomocowe i zawodowe wspierające pracujacce kobiety $z$ niższych warstw, wśród których wymienić należy przede wszystkim funkcjonujące od 1903 r. Stowarzyszenie Personelu Żeńskiego w Handlu i Przemyśle, którego założycielka Zofia Tułodziecka była rzeczniczka szeregu postępowych haseł. Pod zaborem pruskim nie powstała jednak żadna organizacja feministyczna szermująca hasłem równości płci. Konserwatywne i narodowo-demokratyczne sympatie większości miejscowej elity, mające wpływ na oblicze polityczne zaboru, przekreślały tego typu projekty, które uważane były za zamach na dotychczasowy porządek społeczny i sprzeniewierzenie sprawie narodowej. Podporządkowanie działalności kobiet wartościom patriotycznym i religijnym zbieżne było z zadaniami, jakie formułował dla nich dyskurs ideologiczny ruchu narodowego, $z$ którym na początku XX w. coraz wyraźniej identyfikowały się główne wielkopolskie działaczki ${ }^{13}$. Ewa Maj określiła ten model aktywizmu kobiecego mianem „feminizmu narodowego”. W myśl jego założeń kobiety miały zająć się lokalna patriotyczną pracą oświatowo-opiekuńczą, która rozumiana była jako uzupełnienie realizowanego przez mężczyzn programu narodowego, co wyraźnie nawiązywało do poglądów Zygmunta Balickiego na ten temat ${ }^{14}$. Samodzielna działalność kobiet, tj. bez męskiego

12 Grażyna Wyder, „Z dziejów walki o tożsamość narodowa - tajne stowarzyszenie kobiet "Warta»", w: Grażyna Wyder, Tomasz Nodzyński (red.), Polacy - Niemcy - Pogranicze. Studia Historyczne, (Zielona Góra: Oficyna Wydawnicza Uniwersytetu Zielonogórskiego, 2006), 183-200.

13 Eadem, „Wielkopolskie działaczki w ruchu narodowo-demokratycznym na terenie Poznańskiego na przełomie XIX i XX wieku. Szkic do działalności politycznej kobiet”, Czasopismo Naukowe Instytutu Studiów Kobiecych, t. 1 (2), 2017, 48-72; Ewa Maj, „Wzorce aktywności kobiet w Narodowej Demokracji (1893-1939), w: Teresa Kulak, Małgorzata Dajnowicz (red.), Drogi kobiet do polityki (na przestrzeni XVIII-XXI wieku), (Wrocław: Chronikon, 2016), 145-171.

14 Ewa Maj, „Feminizm narodowy", czyli o kobietach w Narodowej Demokracji”, w: Maria Marczewska, Dorota Maj, Marcin Pomarański (red.), Feminizm, (Lublin: Wydawnictwo Uniwersytetu Marii Curie-Skłodowskiej, 2015), 218-220; Joanna Kurczewska, „Pierwsi 
czy kościelnego patronatu, i wykraczająca poza powyższe cele była trudna do zaakceptowania przez opiniotwórcze, konserwatywne kręgi, których organy prasowe krytycznie oceniały takie inicjatywy ${ }^{15}$. Nie oznacza to jednak, że ich nie było. W rezultacie w Wielkopolsce, najbardziej pod tym względem przebadanej części zaboru pruskiego, można wskazać dwa nurty ruchu kobiecego: pierwszy, związany z Kościołem katolickim, w którym dużą rolę odgrywali księża, i drugi, niezależny od Kościoła katolickiego, samodzielny, bo rozwijający się bez „wsparcia na męskim ramieniu" i - według Cecylii Walewskiej, autorki pierwszej historii ruchu kobiecego na ziemiach polskich - postępowy ${ }^{16}$. W obu tych nurtach powstały organizacje dedykowane kobietom pracującym $z$ niższych warstw społecznych, o charakterze zawodowym, oferujące różne formy pomocy i dokształcania (np. działające od 1906 r. Towarzystwo Katolickiej Służby Żeńskiej w Poznaniu ${ }^{17}$ oraz samodzielne, wymienione już wyżej Stowarzyszenie Personelu Żeńskiego w Handlu i Przemyśle) i organizacje skupiające przedstawicielki kręgów mieszczańsko-ziemiańskich, prowadzące działalność oświatową, opiekuńczą i socjalna (np. funkcjonujące od 1903 r. stowarzyszenie „Promień" czy powstałe w 1910 r. Towarzystwo Ziemianek dla Wielkopolski i Pomorza). Oba nurty też na pierwszym planie stawiały kwestię narodowa i oba nurty pod koniec pierwszych lat XX w. zrzeszyły się w odrębnych organizacjach parasolowych. Stowarzyszenia pozostające pod wpływami Kościoła katolickiego, rozwijające się w dużej mierze wśród kobiet $z$ niższych warstw społecznych, weszły w 1906 r. w skład Związku Stowarzyszeń Kobiet Pracujaccych, niezależne zaś od duchowieństwa, zajmujące się według statutu tylko praca oświatowa, w 1909 r. zawiązały Zjednoczenie Towarzystw Kobiecych Oświatowych na Rzeszę Niemiecką ${ }^{18}$.

nacjonaliści polscy i sprawy kobiet”, Archiwum Historii Filozofii i Myśli Społecznej, t. 44, 1999, 198-199; eadem, „Wczesny radykalny nacjonalizmu polski a sprawy kobiet”, w: Andrzej Nowak, Andrzej A. Zięba (red.), Formuły patriotyzmu w Europie Wschodniej i Środkowej od nowożytności do współczesności, (Kraków: Polska Akademia Umiejętności, 2009), 225-226.

15 Jarosław Urbański, Wiecowiczki, 33-39.

16 Cecylia Walewska, Ruch kobiecy w Polsce. Część II, (Warszawa, 1909), 43.

17 Izabela Krasińska, „Sytuacja żeńskiej służby domowej w świetle poznańskiego czasopisma "Ruch Chrześcijańsko-Społeczny» (1902-1910)", Studia Gdańskie, t. 40, 2017, 132-133.

18 Pierwsze zrzeszenie liczyło w 1910 r. 21 stowarzyszeń, a jego organem prasowym było pismo „Gazeta dla Kobiet”, drugie zaś w tym samym czasie, a więc po roku działalności 
Jak wskazują opinie publikowane na łamach ówczesnej prasy, program narodowy miał także $z$ innego powodu kluczowy wpływ na brak szerszego zainteresowania działaczek $z$ zaboru pruskiego hasłami równościowymi, łączącymi się z dążeniem do poprawy statusu kobiet. Poparcie ich oznaczałoby bowiem konieczność współpracy z powstającymi w miastach stowarzyszeniami niemieckiego mieszczańskiego ruchu kobiecego, które rozwijały właśnie tego typu aktywność ${ }^{19}$. W publicystyce wielokrotnie podkreślano, że Polki z zaboru pruskiego na pierwszym miejscu stawiały walkę o zachowanie polskości i - jak pisała Helena Rzepecka, jedna z głównych działaczek wielkopolskich - w tych okolicznościach współdziałanie $z$ Niemkami stanowiłoby „uchybienie godności narodowej”20. $Z$ tego też względu komentarz kończący omawianie publikacji dotyczącej statystyki niemieckich organizacji kobiecych, który ukazał się na łamach poznańskiej „Gazety dla Kobiet” w 1909 r., kończył się zdaniem: „Czy $z$ kobiet polskich w Rzeszy niemieckiej choć jedna należy do takiego stowarzyszenia, wattpimy”21. Głos ten pozostawał jednak w sprzeczności z pojawiajacymi się w prasie notatkami piętnującymi współpracę Polek i Niemek, które przecież jednocześnie wskazywały, że była ona częścia ówczesnej rzeczywistości ${ }^{22}$.

Od końca XIX w. przybywało na ziemiach zaboru pruskiego niemieckich stowarzyszeń kobiecych i to o różnym charakterze, od dobroczynnych przez religijne, patriotyczne, zawodowe (w tym także w środowisku robotniczym) po feministyczne i nacjonalistyczne. Brak systematycznych badań na ten temat nie pozwala na bliższą ich charakterystykę ani ujęcie ilościowe. Wiadomo jednak, że na poczattku XX w. organizacje zwiazane $z$ umiarkowanym i postępowym nurtem mieszczańskiego ruchu kobiecego działały np. w Poznaniu, Toruniu, Bydgoszczy i Gdańsku. Były to przede wszystkim oddziały Stowarzyszenia

\footnotetext{
- 12 stowarzyszeń, a jego organem prasowym był miesięcznik „Zjednoczenie”. Ck, „Praca oświatowa w Poznańskiem”, Gazeta Częstochowska, nr 92, 1910.

19 Marie Wegner, Merkbuch der Frauenbewegung, (Leipzig-Berlin 1908); Agnieszka Szudarek, „Stowarzyszenia niemieckiego mieszczańskiego ruchu kobiecego w miastach zaboru pruskiego na początku XX wieku”, w: Szczepan Wierzchosławski, Aneta Niewęgłowska, Tomasz Krzemiński (red.), W kręgu dwóch kultur. Społeczeństwo polskich ziem zachodnich $w$ XIX i XX stuleciu, (Torun: Wydawnictwo Naukowe Uniwersytetu Mikołaja Kopernika), 193-218.

${ }^{20}$ HR, „Ruch kobiecy”, Głos Wielkopolanek, nr 3, 1908.

21 „Statystyka organizacji kobiecych w Niemczech”, Gazeta dla Kobiet, nr 10, 1909, 78.

22 Zob. m.in.: „Z Wąbrzeźna”, Głos Wielkopolanek, nr 2, 1913, 1-2.
} 
„Frauenwohl” (Verein „Frauenwohl”) działającego w Berlinie pod przewodnictwem Minny Cauer i opowiadajacego się m.in. za przyznaniem kobietom praw wyborczych. $Z$ innych organizacji formułujących radykalne postulaty należy wymienić założoną w Gdańsku filię funkcjonującego od 1904 r. niemieckiego oddziału Międzynarodowej Federacji Abolicjonistycznej (Deutscher Zweig der Internationalen Abolitionistischen Föderation), która powstała w Wielkiej Brytanii w 1874 r. z inicjatywy Josephine Butler $z$ zamiarem doprowadzenia do delegalizacji reglamentowanej prostytucji ${ }^{3}$. Uwage zwracaja także mieszczace się w tym nurcie dwa poznańskie stowarzyszenia. Pierwsze to oddział Związku Ochrony Matek (Bund für Mutterschutz), którego centrala działała od 1905 r. w Berlinie, $z$ Helene Stöcker na czele, dążąc m.in. do zrównania praw dzieci małżeńskich i pozamałżeńskich oraz wprowadzenia edukacji seksualnej, która chroniłaby kobiety przed nieplanowanymi ciążami ${ }^{24}$. Drugie zaś to założone na przełomie 1910 i 1911 r. Stowarzyszenie Praw Wyborczych Kobiet (Verein für Frauenstimmrecht) ${ }^{25}$.

Umiarkowany nurt mieszczańskiego ruchu kobiecego zajmujący się m.in. aktywizowaniem kobiet i edukowaniem ich w zakresie pracy socjalnej reprezentowało natomiast Poznańskie Towarzystwo Popierania Interesów Kobiet (Posener Fraueninteresseverein) ${ }^{26}$. Oprócz tego zabór pruski opleciony był m.in. siecią oddziałów Patriotycznego Stowarzyszenia Kobiet (Vaterländischer Frauenverein), które angażowały się przede wszystkim w opiekę nad niemowlętami, wdrażając w tej dziedzinie wiele nowych rozwiąań, jak i organizacji konfesyjnych, które prowadziły działalność opiekuńczą i edukacyjną wobec kobiet i dzieci²7. Część stowarzyszeń, które tak jak ostatnie $z$ wymienionych, współtworzyły konserwatywny nurt ruchu kobiecego, wraz z nasilaniem się nastrojów nacjonalistycznych obrała kurs antypolski, co było też cechą powołanego

\footnotetext{
${ }^{23}$ Agnieszka Szudarek, „Stowarzyszenia niemieckiego mieszczańskiego ruchu kobiecego”, 202-205, 209.

24 Ibidem, 211.

25 Archiwum Państwowe w Poznaniu, Prezydium Policji, sygn. 4325, 1.

26 Archiwum Państwowe w Poznaniu, Akta miasta Poznania, sygn. 3943, 4-5.

27 Andrea Süchting-Hänger, "Gleichgroße mut'ge Helferinnen" in der weiblichen Gegenwelt. Der Vaterländische Frauenverein und die Politisierung konservativer Frauen 1890-1914", w: Ute Planert (Hrsg.) Nation, Politik und Geschlecht. Frauenbewegung und Nationalismus in der Moderne, (Frankfurt-New York: Campus, 2000), 131-146.
} 
w Poznaniu w 1911 r. oddziału Niemieckiego Stowarzyszenia Kobiet Marchii Wschodniej (Deutscher Frauenverein für die Ostmarken)28.

\section{Niemiecki mieszczański ruch kobiecy - między współpracą a zdradą narodową}

Dla polskich aktywistek z Królestwa Polskiego i Galicji niemiecki mieszczański ruch kobiecy był wzorem do naśladowania zarówno pod względem struktur organizacyjnych, jak i form działalności ${ }^{29}$. Jego program oparty na przekonaniu o odmienności, ale równości płci, operujacy koncepcja duchowego i zinstytucjonalizowanego macierzyństwa oraz głoszący misję cywilizacyjną kobiet, w wielu punktach był zbieżny z poglądami polskich działaczek. Na łamach czasopism dla kobiet wydawanych w Warszawie publicystki zachęcały Wielkopolanki do współpracy $z$ niemieckimi stowarzyszeniami, jednak płynace zza kordonu odpowiedzi przekonywały, że „kwestia kobieca” pod zaborem pruskim jest poza sfera zainteresowania miejscowych działaczek pracujacych przede wszystkim nad utrzymaniem tożsamości narodowej ${ }^{30}$. Niemiecki mieszczański ruch kobiecy, zwłaszcza jego postępowy nurt, jak się wydaje, był gotów na podjęcie wspólnych działań. Jego liderki podkreślały ponadnarodowy i apolityczny charakter organizacji. Niektóre $z$ nich, tj. Minna Cauer, Anita Augspurg i Tony Breitscheid, odpowiedziały na apel polskich działaczek opublikowany na łamach jednego z niemieckich pism i w 1908 r. zaprotestowały przeciwko dyskryminującemu Polaków nowemu prawu o stowarzyszeniach i ustawie wywłaszczeniowej, o czym szeroko informował „Bluszcz”31. „Ster” natomiast przytoczył słowa Tony Breitscheid, przewodniczacej pruskiego oddziału Zwiazku Praw Wyborczych Kobiet (Preußischer Landesverein für Frauenstimmrecht), opublikowane na łamach „Die Frauenbewegung”, organu radykalnego skrzydła mieszczańskiego ruchu kobiecego:

\footnotetext{
${ }^{28}$ Geheimes Staatsarchiv Preussischer Kulturbesitz, Berlin-Dahlem, I. HA Rep. 77, Tit. 662, Nr. 121, 130; Archiwum Państwowe w Poznaniu, Prezydium Policji, sygn. 4326, 1-3. 29 Por. Agata Zawiszewska, „Aktivitätsmodelle der deutschen Frauenbewegung um die Wende vom 19. zum 20. Jahrhundert in gesellschaftlicher und publizistischer Tätigkeit von Paulina Kuczalska-Reinschmit", Colloquia Germanica Stetinensia, t. 25, 2016, 101-120.

30 Z[ofia]. Bielicka, „Rodaczki nasze pod zaborem pruskim”, Bluszcz, nr 1, 1907, 6.

31 J. Orka [Melania Rajchmanowa], „Jak walczą kobiety”, Bluszcz, nr 1, 1908, 9; eadem, „Niemki - o paragrafie 7”, Bluszcz, nr 9, 1908, 94-95.
} 
Niemiecki zwiąek wyborczych praw kobiet zwalczać musi jak najbardziej stanowczo polityke oparta na zasadzie: siła przed prawem! My, kobiety żądające równouprawnienia $z$ mężczyznami, musimy protestować przeciwko rozporządzeniom, które dążą do pozbawienia praw znacznej części ludności. Tak prawo o wywłaszczeniu, jak i żądanie, by Polacy posługiwali się językiem niemieckim w obradach swoich jest istotnym pogwałceniem praw im należnych ${ }^{32}$.

Co istotne, na ziemiach zaboru pruskiego, zwłaszcza w Wielkopolsce, poglądy aktywistek niemieckiego mieszczańskiego ruchu kobiecego oraz promowane przez nie formy aktywizacji i wspierania kobiet także były oceniane pozytywnie, m.in. na łamach „Głosu Wielkopolanek” czy „Dziennika Poznańskiego" ${ }^{33}$. Na uwage zasługuje zwłaszcza cykl artykułów opublikowany w „Głosie Wielkopolanek” w 1908 r., omawiający przyczyny powstania „kwestii kobiecej”, który to w dużej mierze stanowi streszczenie poglądów niemieckich działaczek na ten temat. Co więcej, nieznany autor/autorka przyjmuje jako najadekwatniejszą definicję ruchu kobiecego zawarta w programie Związku Niemieckich Stowarzyszeń Kobiecych (Bund Deutscher Frauenvereine), gdzie stwierdza się, iż dąży on „do ułatwienia zupełnego wewnętrznego rozwoju kobiety i do umożliwienia jej wolnego zewnętrznego oddziaływania na kulturę ludzka" ${ }^{34}$. $\mathrm{Na}$ brak wrogości i zainteresowanie problematyka zwiazana $\mathrm{z}$ „kwestia kobieca" wskazuja także publikowane w polskiej prasie informacje na temat wykładów niemieckich działaczek, które przyjeżdżały m.in. do Poznania na zaproszenie tamtejszych niemieckich stowarzyszeń. W 1908 r., a więc w okresie nasilenia antypolskiej polityki, „Dziennik Poznański” zachęcał do wzięcia udziału w prelekcjach Helene Stöcker zatytułowanych: „Walka o małżeństwo” oraz „Zreformowane małżeństwo i nowa etyka”35.

\section{Współpraca w cieniu konfliktu?}

Okoliczności te wskazuja więc, że pod koniec pierwszych lat XX w. wytworzył się korzystny klimat między niemieckim mieszczańskim

\footnotetext{
32 „Protest Niemieckiego Zwiąku wyborczych praw Kobiet”, Ster, nr 2, 1908, 83-84; „Interpelacja”, Ster, nr 1, 1910, 37-38.

33 „Z ruchu kobiecego”, Dziennik Poznański, nr 118, 1908.

34 „Przyczyny powstania kwestii kobiecej (Odczyt wygłoszony w Czytelni dla kobiet w Gostniu) V", Głos Wielkopolanek, nr 38, 1908, 45.

35 Dziennik Poznański, nr 275, 1908.
} 
ruchem kobiecym a środowiskiem polskich działaczek $\mathrm{z}$ zaboru pruskiego, którego nie powinno się marginalizować w badaniach nad aktywizacją i samoorganizacją Polek na tym obszarze. Stanowi on ważki kontekst, który może pozwolić dostrzec niezauważone dotąd powiązania ideowe czy też formy współpracy między funkcjonującymi równolegle od pierwszych lat XX w. strukturami organizacyjnymi skupiajacymi Polki i Niemki. Nadzieje na tego typu ustalenia i tym samym przełamanie opartej na paradygmacie konfliktu narracji na temat relacji między nimi przynoszą wyniki badań nad biografia pochodzacej z Gdańska Käthe Schirmacher, aktywistki postępowego niemieckiego mieszczańskiego ruchu kobiecego, która ok. 1906 r. poparła antypolski program Niemieckiego Zwiazku Marchii Wschodniej (Hakaty). Jej wolta, kłopotliwa zreszta dla niemieckich działaczek, które chciały zachować neutralność polityczna i nie angażować się w polsko-niemiecki konflikt narodowy, w starszej polskiej historiografii jest eksponowana jako przykład nacjonalistycznego zaangażowania Niemek. Nie ulega watpliwości, że Käthe Schirmacher dażyła do tego, aby we wschodnich prowincjach państwa pruskiego ruch kobiecy zintegrować $z$ antypolską działalnością Hakaty. Wspierana przez bydgoską działaczkę Marthe Schnee miała nawet w tej dziedzinie pewne sukcesy. Jednak nie wszystkie niemieckie aktywistki poparły tę koncepcję. Badaczki zajmujące się biografia K. Schirmacher wskazują, że jej poglądy spotkały się ze zdecydowanym sprzeciwem Marie Kosser, liderki zwiazanego z mieszczańskim umiarkowanym ruchem kobiecym Poznańskiego Stowarzyszenia Popierania Interesów Kobiet. Pod wpływem negatywnych komentarzy prasowych, jakie wywołało antypolskie wystapienie K. Schirmacher na zjeździe niemieckich organizacji kobiecych (Ostdeutschen Frauentag) w Olsztynie, w październiku 1908 r. M. Kosser wycofała przekazane jej latem zaproszenie do wygłoszenia w Poznaniu wykładu pt. Was erwirbt die Hausfrau? ${ }^{36}$. Według autorek biografii K. Schirmacher zdecydowana postawa poznańskiej działaczki, która także przy innych okazjach wypowiadała się przeciwko łączeniu emancypacyjnego

\footnotetext{
36 Johanna Gehmacher, Elisa Heinrich, Corinna Oesch, Käthe Schirmacher. Agitation und Autobiografische Praxis zwischen radikaler Frauenbewegung und völkischer Politik, (Wien-Köln-Weimar: Böhlau Verlag, 2018), 398-399; Anke Walzer, Käthe Schirmacher. Eine deutsche Frauenrechtlerin auf dem Wege vom Liberalismus zum konservativen Nationalismus, (Pfeffenweiler: Centaurus-Verlagsgesellschaft, 1991), 72; Romana Pachucka, Pamiętniki z lat 1886-1914, (Wrocław: Ossolineum, 1958), 204; „Arcyhakatystka”, Głos Wielkopolanek, nr 30, 1908, 1.
} 
ruchu kobiecego $z$ polityka, w tym zwłaszcza w wydaniu nacjonalistycznym $^{37}$, zapoczątkowała stopniowe odsuwanie Schirmacher od funkcji kierowniczych w Niemieckim Zwiazku Praw Wyborczych Kobiet (Deutscher Verband für Frauenstimmrecht), z którym ostatecznie rozstała się w $1913 r{ }^{38}$ Najistotniejsze znaczenie ma jednak fakt, że poglądy Kosser wpłynęły na charakter kierowanego przez nia poznańskiego stowarzyszenia, gdyż wraz z Niemkami działały w nim także Polki ${ }^{39}$.

Ustalenia te przełamuja więc dotychczasowe przekonanie o braku współpracy między kobietami obu narodowości. Okazuje się, że cele emancypacyjnego Poznańskiego Stowarzyszenia Popierania Interesów Kobiet, koncentrujacce się wokół pracy społecznej, mogły się stać spoiwem budującym ich współdziałanie. Co więcej, jeśli w tle tego współdziałania nie pojawiała się nacjonalistyczna propaganda lub działania o charakterze antypolskim, kontakty Polek i Niemek nie spotykały się też z krytyka w prasie. Ukazujący się w Poznaniu „Głos Wielkopolanek” bez jakiegokolwiek negatywnego wartościowania wymienił Polki należące do stowarzyszenia kierowanego przez M. Kosser. Były nimi: Magdalena Zerbowa, profesorowa M. Cybichowska i Pelagia Biegańska, które równolegle działały w Towarzystwie Pań Miłosierdzia św. Wincentego à Paulo (Zerbowa) i w Towarzystwie Opieki nad Dziećmi Katolickimi (Biegańska i Cybichowska) ${ }^{40}$. Magdalena Zerbowa należała też do innego niemieckiego stowarzyszenia, w którym - jak donosił „Dziennik Poznański” bez cienia krytyki - działało wielu Polaków, tj. istniejącego w Poznaniu od przełomu XIX i XX w. Towarzystwa Opieki nad Chorymi Robotnikami ${ }^{41}$.

\footnotetext{
37 Johanna Gehmacher, Elisa Heinrich, Corinna Oesch, Käthe Schirmacher, Agitation und Autobiografische, 399.

38 Ibidem, 534; Anne-Laure Briatte, Bevormundete Staatsbürgerinnen. Die radikale Frauenbewegung im Deutschen Kaiserreich, (Frankfurt-New York: Campus Verlag, 2020), 361.

39 Johanna Gehmacher, Elisa Heinrich, Corinna Oesch, Käthe Schirmacher, Agitation und Autobiografische, 399.

40 Elżbieta Czartoryska, ks. Edward Likowski, Sprawozdanie z 50-cio letniej działalności Towarzystwa Pań Miłosierdzie św. Wincentego a Paulo w Poznaniu, (Poznań, 1904), 14; „Tow. Opieki nad dziećmi katolickiemi”, Postęp, nr 97, 1910. O przynależności wymienionych kobiet do Stowarzyszenia Popierania Interesów Kobiet informują również archiwalia. Archiwum Państwowe w Poznaniu, Akta miasta Poznania, sygn. 3943, k. 5.

41 „Towarzystwo opieki nad chorymi robotnikami”, Dziennik Poznański, nr 111, 1908, 11.
} 


\section{W stronę historii transnarodowej}

Wyjaśnienie tej współpracy wskazuje na konieczność włączenia do badań nad problematyka kobieca założeń teoretycznych wykorzystywanych $\mathrm{w}$ analizach procesów przebiegających na polsko-niemieckim pograniczu kulturowym, czy też szerzej, odwołania się do historii transnarodowej ${ }^{42}$. Według wydanego w Nowym Jorku w 2009 r. słownika poświęconego tej perspektywie badawczej historia transnarodowa zajmuje się badaniem wszystkiego, co przepływa i krzyżuje się ponad państwami i społeczeństwami ${ }^{43}$. Oznacza zatem wyjście poza tradycyjne, narodowe wzory interpretacji i dostrzeżenie ruchów, prądów czy idei, które, jak pisze Ian Tyrrell w swoich rozważaniach o przewrocie transnarodowym w amerykańskiej historiografii, przekraczały granice organizmów politycznych ${ }^{44}$. Historia transnarodowa jest więc alternatywa dla interpretacji przyjmujących założenia - jak to określił Pierre-Yves Saunier metodologii narodowej (methodological nationalism), której efektem były np. koncepcje deutsche Sonderweg czy amerykańskiej wyjątkowości. Nie bada więc narodów jako niezmiennych całości, ale procesy formowania, cyrkulacji i łączności oraz wpływy decydujące o kształcie tworzonych przez ludzi struktur organizujących im życie, jak również poszukuje odpowiedzi na pytanie, jak powstały, co działa między nimi i poprzez nie ${ }^{45}$. Jest to więc podejście relacyjne, które obejmuje także transfer treści kulturowych. W założeniach metodologicznych badań nad transferem kulturowym główni jego teoretycy, tj. Michael Werner i Michel Espagne, odwołali się do dorobku studiów kulturowych (cultural studies) oraz badań nad komunikacją i uwypuklili analizę kontekstu pochodzenia dobra kulturowego, a także okoliczności towarzyszące jego odbiorowi. Zwrócili

\footnotetext{
42 Michael Müller, „Historia transnarodowa, historia wzajemnych oddziaływań i (po) dzielone miejsca pamięci. Tradycje i wyzwania metodologiczne”, w: Robert Traba, Hans Henning Hahn (red.), Polsko-niemieckie miejsca pamięci, t. 4: Refleksje metodologiczne, (Warszawa: Wydawnictwo Naukowe Scholar, 2013), 33-47.

43 Akira Iriye, Pierre-Yves Saunier, „Introduction”, w: Akira Iriye, Pierre-Yves Saunier (eds.), The Palgrave Dictionary of Transnational History. From the mid-19 th to the present day, (New York: Palgrave Macmillan, 2009), XVIII.

44 Ian Tyrrell, „Reflections on the transnational turn in United States history: theory and practice", Journal of Global History, vol. 4, iss. 3, 2009, 453-474; Christopher A. Bayly, Sven Beckert, Matthew Connelly, Isabel Hofmeyr, Wendy Kozol, Patricia Seed, „AHR Conversation: On Transnational History", The American Historical Review, vol. 111, iss. 5, 2006, 1441-1464.

45 Pierre-Yves Saunier, Transnational History, (Basingstoke: Palgrave Macmillan, 2013), 2.
} 
też uwagę na aktorów i środek transferu (medium). Biorąc pod uwagę te czynniki, przyjęli, że transfer określonych treści wynikał $z$ interesów aktorów biorących w nim udział, a wybrane media decydowały o samym procesie transmisji ${ }^{46}$. Według Wernera i Espagne'a potrzeby kultury odbierajacej, czyli tej przyjmujacej obce, zewnętrzne dobra, decydowały o selektywnej recepcji i aktywnym zawłaszczeniu, a co za tym idzie zmianie znaczeń transferowanych treści, co miało kluczowe znaczenie dla procesu komunikacji. Transfer kulturowy wraz $z$ innymi nawiąującymi do niego podejściami, m.in. historia splątaną (entangled history), l'histoire croisée, czy też wspomniana już wyżej historia wzajemnych oddziaływań, stanowi bardzo istotne uzupełnienie dotychczasowych perspektyw badań historycznych ${ }^{47}$. Umożliwia bowiem analizowanie ponadnarodowych procesów wymiany, reinterpretacji i interakcji, które mogą ukazać sieci powiazań budujących nadrzędne struktury, w których zacierają się granice i funkcjonują ślady różnych kontekstów transferowanych treści. Struktury te moga też kierować się własną logika oraz rozwijać cechy, które nie maja pochodzenia narodowego czy narodowych znaczeń, tudzież generować własne konteksty ${ }^{48}$.

Zwrot transnarodowy sprzyja więc znoszeniu ograniczeń wynikajacych $z$ optyki narodowej przyjętej jeszcze przez dziewiętnastowiecznych historyków. Według Adama Thomasa ten sposób patrzenia na dzieje stał się analityczna „klatką" i w wielu przypadkach stracił swoja moc wyjaśniająca. Przestrzeń jednego narodu powoduje bowiem badanie tylko fragmentu problemu, który w określony sposób zaistniał w jego ramach, i w konsekwencji utratę $z$ pola widzenia złożonych treści oraz kontekstów

\footnotetext{
46 Por. Lidia Jurek, „Teoria "transferu kulturowego" i jej zastosowanie w badaniach historii społecznej (na przykładzie polsko-włoskich kontaktów doby Risorgimento)", Studia z Historii Społeczno-Gospodarczej XIX i XX wieku, t. 6, 2009, 32-44; Dominik Pick, „Czym jest transfer kultury? Transfer kultury a metoda porównawcza. Możliwości zastosowania transferts culturels na gruncie polskim”, w: Mirosława Zielińska, Marek Zybura (red.), Monolog, dialog, transfer. Relacje kultury polskiej i niemieckiej w XIX i XX wieku, (Wrocław: Centrum Willy'ego Brandta, 2013), 93-108.

47 Por. Michael Werner, Bénédicte Zimmermann, „Vergleich, Transfer, Verflechtung. Der Ansatz der Historie croisée und die Herausforderung des Transnationalen", Geschichte und Gesellschaft, Bd. 28, 2002, 607-636; eidem, „Beyond Comparison: Histoire croisée and the Challenge of Reflexivity", History and Theory, vol. 45, 2006, 30-50.

48 Oliver Janz, Daniel Schönpflug, „Introduction”, w: Oliver Janz, Daniel Schönpflug (eds.), Gender History in a Transnational Perspective. Networks, Biographies, Gender Orders, (New York-Oxford: Berghahn, 2014), 3-5.
} 
istniejących poza nimi. To niczym analizowanie odciętej wiązki z systemu korzeniowego rozrastającego się drzewa ${ }^{49}$.

\section{Zamiast zakończenia. Zwrot transnarodowy w badaniach nad „kwestią kobiecą” pod zaborem pruskim}

Zasygnalizowane wcześniej podejście teoretyczne inspiruje także badaczki i badaczy zajmujących się problematyką kobiecą oraz studiami nad płcią ${ }^{50}$. W rodzimej nauce przykładem jest najnowsza publikacja Iwony Dadej, w której autorka przedstawiła transnarodowe przestrzenie działania kobiet zwiazanych ze środowiskiem akademickim w okresie międzywojennym w Polsce i w Niemczech ${ }^{51}$. Potencjał poznawczy transnarodowości jako kategorii analityczno-interpretacyjnej pozwala mieć nadzieję, że zastosowanie go do badań nad aktywnością Polek i Niemek pod zaborem pruskim odsłoni niezauważany, a ujawniający się w działaniu transfer idei, które w tym samym czasie zafunkcjonowały w ramach narodowych ruchów kobiecych. Chodzi tu $z$ jednej strony o osobiste relacje między działaczkami, trudne do wychwycenia, gdyż zwykle właśnie ze względów narodowych zatajane i pomijane w dokumentach osobistych, $z$ drugiej zaś o relacje między polskimi a niemieckimi organizacjami oraz między nimi a rozwijającym się od końca XIX w. międzynarodowym (od strony struktur organizacyjnych) ruchem kobiecym. Trzeba bowiem podkreślić, że program międzynarodowego ruchu kobiecego nie był jednolity i zwykle bywa utożsamiany $z$ kwestia praw wyborczych dla kobiet, walką $z$ podwójną moralnością, prostytucją i handlem kobietami.

Powołana w 1888 r. Międzynarodowa Rada Kobiet (International Council of Women) nie głosiła jednak radykalnych haseł feministycznych, stojąc na stanowisku równości, ale jednak odmienności płci i tym samym ich różnych zadań. Założycielki uważały, że zorganizowany ruch kobiecy powinien w szczególny sposób wspierać rodziny i tym samym

\footnotetext{
49 Adam Thomas, „Transnational History. A Program for Research, Publishing, and Teaching", Yearbook of Transnational History, vol. 1, 2018, 1.

50 Zob. m.in. Pernilla Jonsson, Silke Neunsinger, Joan Sangster, Crossing Boundaries. Women's Organizing in Europe and the Americas, 1880s-1940s, (Uppsala: Uppsala Universitet, 2007); Oliver Janz, Daniel Schönpflug (eds.), Gender History in a Transnational Perspective. Networks, Biographies, Gender Orders, (New York-Oxford: Berghahn, 2014). 51 Iwona Dadej, Beruf und Berufung transnational. Deutsche und polnische Akademikerinnen in der Zwischenkriegszeit, (Osnabrück: fibre Verlag, 2019).
} 
włączyć się w podejmowane wówczas reformy społeczne mające łagodzić negatywne skutki transformacji gospodarczych, które były częścia doświadczenia kobiet $z$ różnych warstw społecznych. Ten umiarkowany program stał się zreszta przyczyna powołania odrębnej międzynarodowej organizacji stawiajacej sobie za cel uzyskanie praw wyborczych dla kobiet. Doszło do tego w 1904 r. w Berlinie, podczas zorganizowanego przez Niemki międzynarodowego zjazdu działaczek ruchu kobiecego ${ }^{52}$.

Większość $z$ nich dużo miejsca poświęcała jednak nie prawom politycznym, ale edukacji i pracy kobiet, wspieraniu matek czy opiece nad dziećmi ${ }^{33}$. Ten maternalny wymiar ruchu sprzyjał tworzeniu gęstej sieci nieformalnych, osobistych powiazań między nimi, które stawały się kanałami transmisyjnymi nowych koncepcji i idei, uzupełniając kluczową w tym względzie rolę prasy i kongresów Międzynarodowej Rady Kobiet. Jest to o tyle istotne, że transformacje społeczno-gospodarcze w cywilizacji Zachodu spowodowały, że w poszczególnych państwach kobiety samoorganizowały się, by rozwiazać zwykle te same problemy, i wybierały tożsame lub podobne sposoby radzenia sobie $z$ nimi.

Podejście transnarodowe stanowi więc perspektywę umożliwiajacą badanie i wyjaśnianie tych zbieżności jako działań podejmowanych w ramach jednej kultury opartej na wspólnocie wartości i dążeń. Pod zaborem pruskim perspektywa ta rodzi jednak szereg pytań dotyczących aktywności Polek i Niemek, a dokładniej aktywności stowarzyszeń, w ramach których działały. Mianowicie, czy mamy tu do czynienia $z$ narodowymi adaptacjami programu emancypacyjnego upowszechnianego przez prasę, międzynarodowe zjazdy kobiet lub sieć osobistych powiazań, czy też raczej niemiecki ruch kobiecy, który przyswoił sobie wcześniej nowatorskie koncepcje sprzyjajace rozwiazaniu różnych aspektów „kwestii kobiecej”, był źródłem ich transferu przynajmniej do części polskich stowarzyszeń? $Z$ dotychczasowych badań wynika bowiem, że działaczki niemieckiego ruchu kobiecego były aktywne na forum międzynarodowym, miały liczne kontakty w Stanach Zjednoczonych i Wielkiej Brytanii ${ }^{54}$.

52 Organizacją tą był Międzynarodowy Sojusz na Rzecz Praw Wyborczych Kobiet (International Women Suffrage Alliance). Agnieszka Szudarek, „Berliński międzynarodowy zjazd działaczek ruchu kobiecego w 1904 r. w świetle tygodników warszawskich", Czasopismo Instytutu Studiów Kobiecych, t. 1 (4), 2018, 19-23.

${ }^{53}$ Leila J. Rupp, Worlds of Women. The Making of an International Women's Movement, (Princeton: Princeton University Press, 1997), 15-20.

54 Zob. m.in. Kerstin Wolff, „Herrenmoral: Anna Pappritz and abolitionism in Germany”, Women's History Review, vol. 17, iss. 2, 2008, 225-237; Ute Frevert, „National oder 
K. Schirmacher uczestniczyła np. w kongresie kobiet, który się odbył w 1893 r. (World's Congress of Representative Women) w Chicago, i po powrocie jeździła po Niemczech z wykładami sprawozdawczymi, goszcząc także w swoim rodzinnym Gdańsku ${ }^{55}$.

O obecności Polek na forum międzynarodowego ruchu kobiet, zwłaszcza $z$ zaboru pruskiego, niewiele wiadomo, jednak nowe koncepcje transferowane były także innymi kanałami ${ }^{56}$. W związu $z$ tym należałoby spojrzeć na działalność polskich organizacji pod zaborem pruskim poprzez treści będące przedmiotem tego transferu. Czy np. pod określeniami typu praca charytatywna, dobroczynna lub dzieła miłosierdzia nie kryła się nowoczesna praca socjalna, w której kreowaniu istotna rolę odgrywały Niemki z Alice Salomon na czele? Skąd polskie organizacje zawodowe lub stowarzyszenia wspierające kobiety pracujacce czerpały wzory, organizując w ostatnich latach przed I wojna światową biura porad prawnych, stacje opieki dworcowej, pomoc kobietom w połogu czy kursy socjalne, które przecież nie stanowiły polskiej specyfiki? Czy przejmowały je od Niemek i interpretowały narodowo, czy też korzystały ze wzorów upowszechnianych przez międzynarodowy ruch kobiecy, dostosowując je do polskich warunków? Założenia teoretyczne badania transferu pozwalaja śledzić takie zapożyczenia, określać ich źródła i szukać odpowiedzi na pytanie o to, co i z jakiego powodu było adaptowane. Koncepcja „świata przeżywanego”, a więc, jak to określił Robert Traba, zbioru wspólnych wartości, wyobrażeń, opinii, które tworza przesłankę do działania ${ }^{57}$, może stać się drogą do poszukiwania znaczeń i sensów towarzyszących wspólnym, przemilczanym lub niedostrzeżonym działaniom kobiet obu tych narodowości.

International. Die internationalen Beziehungen der deutschen bürgerlichen Frauenbewegung”, Feministische Studien, Bd. 12, H. 2, 1994, 34-52; Anja Schüler, Kerstin Wolff, „Es sind die gleichen Überzeugungen, die die Frauen aller Länder erfüllen..." Zur Enstehung von internationalen Netzwerken in den Frauenbewegungen", w: Eva Schöck-Quinteros, Anja Schüler, Annika Wilmers, Kerstin Wolff (Hrsg.), Politische Netzwerkerinnen. Internationale Zusammenarbeit von Frauen 1830-1960, (Berlin: trafo, 2007), 13-26; Susanne Schötz, „Jenseits von Grenzen. Transnationale Kommunikation und transnationale Akteurinnen im Umfeld des Allgemeinen Deutschen Frauenvereins", w: Eva Schöck-Quinteros, Anja Schüler, Annika Wilmers, Kerstin Wolff (Hrsg.), Politische Netzwerkerinnen, 79-101. 55 Johanna Gehmacher, „Moderne Frauen, die Neue Welt und der alte Kontinent”, Österreichische Zeitschrift für Geschichtswissenschaften, Bd. 22, H. 1, 2011, 16-40.

56 Por. Dionizja Wawrzykowska-Wierciochowa, „O udziale Polek w międzynarodowym ruchu kobiecym", Pamiętnikarstwo Polskie, nr 1-4, 1976, 59-72.

57 Robert Traba, „Procesy akulturacji/asymilacji w perspektywie badań historycznych”, 12. 
W ten sposób skontekstualizowana aktywność Polek i Niemek stwarza szansę na ukazanie ruchu kobiecego pod zaborem pruskim w zupełnie nowym świetle.

\section{Bibliografia}

\section{Źródla archiwalne}

Archiwum Państwowe w Poznaniu.

Akta miasta Poznania, sygn. 3943.

Prezydium Policji, sygn. 4325, 4326.

Geheimes Staatsarchiv Preussischer Kulturbesitz, Berlin-Dahlem, I. HA Rep. 77, Tit. 662, Nr. 121, 130.

\section{Prasa}

Bluszcz, nr 1, 1907.

Bluszcz, nr 1, 1908.

Bluszcz, nr 9, 1908.

Dziennik Poznański, nr 111, 1908.

Dziennik Poznański, nr 118, 1908.

Dziennik Poznański, nr 275, 1908.

Gazeta Częstochowska, nr 92, 1910.

Gazeta dla Kobiet, nr 10, 1909.

Głos Wielkopolanek, nr 2, 1913.

Głos Wielkopolanek, nr 30, 1908.

Głos Wielkopolanek, nr 38, 1908.

Głos Wielkopolanek, nr 3, 1908.

Postęp, nr 97, 1910.

Ster, nr 1, 1910.

Ster, nr 2, 1908.

\section{Publicystyka}

Czartoryska, Elżbieta. Likowski, Edward, ks. Sprawozdanie z 50-cio letniej działalności Towarzystwa Pań Miłosierdzie św. Wincentego à Paulo w Poznaniu, (Poznań, 1904). 
Walewska, Cecylia. Ruch kobiecy w Polsce. Część II, (Warszawa, 1909).

Wegner, Marie. Merkbuch der Frauenbewegung, (Leipzig-Berlin 1908).

\section{Pamiętniki}

Pachucka, Romana. Pamiętniki z lat 1886-1914, (Wrocław: Ossolineum, 1958).

\section{Opracowania}

Baszko, Agnieszka. „Organizowanie się kobiet polskich w Poznańskiem na przełomie XIX i XX wieku", w: Agnieszka Janiak-Jasińska, Katarzyna Sierakowska, Andrzej Szwarc (red.), Działaczki społeczne, feministki, obywatelki..., Samoorganizowanie sie kobiet na ziemiach polskich po 1918 roku (na tle porównawczym), t. 2, (Warszawa: Neriton, 2009), 292-298.

Baszko, Agnieszka. „Towarzystwo Pomocy Naukowej dla Dziewcząt w Wielkim Księstwie Poznańskim w latach 1871-1918”, Studia Historica Slavo-Germanica, t. 26, 2004/2005, 99-141.

Bayly, Christopher A. Beckert, Sven. Connelly, Matthew. Hofmeyr, Isabel. Kozol, Wendy. Seed, Patricia. „AHR Conversation: On Transnational History", The American Historical Review, vol. 111, iss. 5, 2006, 1441-1464.

Blobaum, Robert. "Kwestia kobieca” w Królestwie Polskim (1900-1914)”, w: Agnieszka Janiak-Jasińska, Katarzyna Sierakowska, Andrzej Szwarc (red.), Działaczki społeczne, feministki, obywatelki... Samoorganizowanie się kobiet na ziemiach polskich do 1918 roku (na tle porównawczym), (Warszawa: Neriton, 2018), 37-56.

Briatte, Anne-Laure. Bevormundete Staatsbürgerinnen. Die radikale Frauenbewegung im Deutschen Kaiserreich, (Frankfurt-New York: Campus Verlag, 2020).

Dadej, Iwona. Beruf und Berufung transnational. Deutsche und polnische Akademikerinnen in der Zwischenkriegszeit, (Osnabrück: fibre Verlag, 2019).

Frevert, Ute. „National oder International. Die internationalen Beziehungen der deutschen bürgerlichen Frauenbewegung", Feministische Studien, Bd. 12, H. 2, 1994, 34-52. 
Gehmacher, Johanna. „Moderne Frauen, die Neue Welt und der alte Kontinent”, Österreichische Zeitschrift für Geschichtswissenschaften, Bd. 22, H. 1, 2011, 16-40.

Gehmacher, Johanna. Heinrich, Elisa. Oesch, Corina. Käthe Schirmacher. Agitation und Autobiografische Praxis zwischen radikaler Frauenbewegung und völkischer Politik, (Wien-Köln-Weimar: Böhlau Verlag, 2018). Iriye, Akira. Saunier, Pierre-Yves. „Introduction”, w: Akira Iriye, Pierre-Yves Saunier (eds.), The Palgrave Dictionary of Transnational History. From the mid-19 $9^{\text {th }}$ to the present day, (New York: Palgrave Macmillan, 2009), XVII-XX.

Janz, Oliver. Schönpflug, Daniel. „Introduction”, w: Oliver Janz, Daniel Schönpflug (eds.), Gender History in a Transnational Perspective. Networks, Biographies, Gender Orders (New York-Oxford: Berghahn, 2014), $1-24$.

Janz, Oliver. Schönpflug Daniel (eds.), Gender History in a Transnational Perspective. Networks, Biographies, Gender Orders, (New York-Oxford: Berghahn, 2014).

Jaworski, Rudolf. „Kilka refleksji nad dziejami Wielkopolanek w XIX i na poczatku XX wieku", w: Anna Żarnowska, Andrzej Szwarc (red.), Kobieta $i$ społeczeństwo na ziemiach polskich $w$ XIX wieku, (Warszawa: DiG, 1995), 21-28.

Jaworski, Rudolf. „Polish Women and the Nationality Conflict in the Province of Posen at the Turn of the Century", w: Rudolf Jaworski, Bianka Pietrow-Ennker (eds.), Women in Polish Society, (New York: Columbia University Press, 1992), 53-70.

Jonsson, Pernilla. Neunsinger, Silke. Sangster, Joan. Crossing Boundaries. Women's Organizing in Europe and the Americas, 1880s-1940s, (Uppsala: Uppsala Universitet, 2007).

Jurek, Lidia. „Teoria "transferu kulturowego» i jej zastosowanie w badaniach historii społecznej (na przykładzie polsko-włoskich kontaktów doby Risorgimento)", Studia z Historii Społeczno-Gospodarczej XIX i XX wieku, t. 6, 2009, 32-44.

Kaelble, Hartmut. „Die interdisziplinären Debatten über Vergleich und Transfer", w: Hartmut Kaelble, Jürgeb Schriewer (Hrsg.), Vergleich und Transfer. Komparatistik in den Sozial-, Geschichte- und Kulturwissenschaften, (Frankfurt-New York: Campus Verlag, 2003), 469-493. 
Kanafocka, Patrycja. Polki w zaborze pruskim 1793-1918. Dwie przestrzenie edukacyjne, publiczna i prywatna, (Opalenica: Wydawnictwo Opalgraf, 2014).

Krasińska, Izabela. „Sytuacja żeńskiej służby domowej w świetle poznańskiego czasopisma "Ruch Chrześcijańsko-Społeczny» (1902-1910)", Studia Gdańskie, t. 40, 2017, 124-135.

Kurczewska, Joanna. „Pierwsi nacjonaliści polscy i sprawy kobiet”, Archiwum Historii Filozofii i Myśli Społecznej, t. 44, 1999, 191-201.

Kurczewska, Joanna. „Wczesny radykalny nacjonalizm polski a sprawy kobiet”, w: Andrzej Nowak, Andrzej A. Zięba (red.), Formuły patriotyzmu $w$ Europie Wschodniej i Środkowej od nowożytności do współczesności, (Kraków: Polska Akademia Umiejętności, 2009), 219-228.

Maj, Ewa. „Feminizm narodowy”, czyli o kobietach w Narodowej Demokracji”, w: Maria Marczewska, Dorota Maj, Marcin Pomarański (red.), Feminizm, (Lublin: Wydawnictwo Uniwersytetu Marii Curie-Skłodowskiej, 2015), 217-229.

Maj, Ewa. „Wzorce aktywności kobiet w Narodowej Demokracji (1893-1939)”, w: Teresa Kulak, Małgorzata Dajnowicz (red.), Drogi kobiet do polityki (na przestrzeni XVIII-XXI wieku), (Wrocław: Chronikon, 2016), 145-171.

Matwiejczyk, Witold. Niemieccy katolicy $w$ Poznańskiem a polityka narodowościowa rzadu pruskiego 1871-1914, (Lublin: Wydawnictwo KUL, 2009).

Molik, Witold. Traba, Robert (red.), Procesy akulturacji/asymilacji na pograniczu polsko-niemieckim w XIX i XX wieku, (Poznań: Instytut Historii UAM, 1999).

Molik, Witold. „Problem akulturacji na pograniczu polsko-niemieckim na przykładzie społeczeństwa polskiego w Poznańskiem w XIX i na początku XX wieku", w: Edward Włodarczyk (red.), Pogranicze polsko-niemieckie. Przeszłość. Teraźniejszość. Przyszłość, (Szczecin: Wydawnictwo Naukowe Uniwersytetu Szczecińskiego, 2001), 43-60.

Molik, Witold. „Procesy asymilacyjne i akulturacyjne w stosunkach polsko-niemieckich w XIX i na początku XX wieku. Stan i postulaty badań", w: Witold Molik, Robert Traba (red.), Procesy akulturacji/asymilacji na pograniczu polsko niemieckim w XIX i XX wieku, (Poznań: Instytut Historii UAM, 1999), 65-96.

Müller, Michael. „Historia transnarodowa, historia wzajemnych oddziaływań i (po)dzielone miejsca pamięci. Tradycje i wyzwania metodologiczne”, w: 
Robert Traba, Hans Henning Hahn (red.), Polsko-niemieckie miejsca pamięci, t. 4: Refleksje metodologiczne, (Warszawa: Wydawnictwo Naukowe Scholar, 2013), 33-47.

Pick, Dominik. „Czym jest transfer kultury? Transfer kultury a metoda porównawcza. Możliwości zastosowania transferts culturels na gruncie polskim", w: Mirosława Zielińska, Marek Zybura (red.), Monolog, dialog, transfer. Relacje kultury polskiej i niemieckiej w XIX i XX wieku, (Wrocław: Centrum Willy'ego Brandta, 2013), 93-108.

Rexheuser, Rex. „Wprowadzenie”, w: Witold Molik, Robert Traba (red.), Procesy akulturacji/asymilacji na pograniczu polsko niemieckim $w$ XIX i XX wieku, (Poznań: Instytut Historii UAM, 1999), 7-14.

Rupp, Leila J. Worlds of Women. The Making of an International Women's Movement, (Princeton: Princeton University Press, 1997).

Saunier, Pierre-Yves. Transnational History, (Basingstoke: Palgrave Macmillan, 2013).

Schötz, Susanne. „Jenseits von Grenzen. Transnationale Kommunikation und transnationale Akteurinnen im Umfeld des Allgemeinen Deutschen Frauenvereins”, w: Eva Schöck-Quinteros, Anja Schüler, Annika Wilmers, Kerstin Wolff (Hrsg.), Politische Netzwerkerinnen. Internationale Zusammenarbeit von Frauen 1830-1960, (Berlin: trafo, 2007), 79-101.

Schüler, Anja. Wolff, Kerstin. „Es sind die gleichen Überzeugungen, die die Frauen aller Länder erfüllen..." Zur Enstehung von internationalen Netzwerken in den Frauenbewegungen”, w: Eva Schöck-Quinteros, Anja Schüler, Annika Wilmers, Kerstin Wolff (Hrsg.), Politische Netzwerkerinnen. Internationale Zusammenarbeit von Frauen 1830-1960, (Berlin: trafo, 2007), 13-26.

Stegmann, Natali. "Je mehr Bildung, desto polnischer»: Die Nationalisierung polnischer Frauen in der Provinz Posen (1870-1914)", w: Ute Grau (Hrsg.), Frauen und Nation, (Tübingen: Silberburg-Verlag, 1996), 165177.

Stegmann, Natali. „Wielkopolskie wzorce kobiecej aktywności społecznej w życiu codziennym kobiet na przełomie XIX i XX wieku”, w: Anna Żarnowska, Andrzej Szwarc (red.), Kobieta i kultura życia codziennego. Wiek XIX i XX, (Warszawa: DiG, 1997), 353-369. 
Stegmann, Natali. Die Töchter der geschlagenen Helden. „Frauenfrage“, Feminismus und Frauenbewegung in Polen 1863-1919, (Wiesbaden: Harrassowitz Verlag, 2000).

Süchting-Hänger, Andrea. "Gleichgroße mut'ge Helferinnen" in der weiblichen Gegenwelt. Der Vaterländische Frauenverein und die Politisierung konservativer Frauen 1890-1914", w: Ute Planert (Hrsg.), Nation, Politik und Geschlecht. Frauenbewegung und Nationalismus in der Moderne, (Frankfurt-New York: Campus, 2000), 131-146.

Szudarek, Agnieszka. „Berliński międzynarodowy zjazd działaczek ruchu kobiecego w 1904 r. w świetle tygodników warszawskich", Czasopismo Instytutu Studiów Kobiecych, t. 1 (4), 2018, 9-46.

Szudarek, Agnieszka. „Stowarzyszenia niemieckiego mieszczańskiego ruchu kobiecego w miastach zaboru pruskiego na poczatku XX wieku", w: Szczepan Wierzchosławski, Aneta Niewęgłowska, Tomasz Krzemiński (red.), W kręgu dwóch kultur. Społeczeństwo polskich ziem zachodnich w XIX i XX stuleciu, (Torun: Wydawnictwo Naukowe Uniwersytetu Mikołaja Kopernika), 193-218.

Thomas, Adam. „Transnational History. A Program for Research, Publishing, and Teaching", Yearbook of Transnational History, vol. 1, 2018, 1-10.

Tilse, Mark. Transnationalism in the Prussian East. From National Conflict to Synthesis 1871-1914, (Basingstoke: Palgrave Macmillan, 2011).

Traba, Robert (red.), Akulturacja/asymilacja na pograniczach kulturowych Europy Środkowo-Wschodniej w XIX i XX wieku, t. 1: Stereotypy i pamięć, (Warszawa: Oficyna Wydawniczo-poligraficzna „Konika”, 2009).

Traba, Robert (red.), Akulturacja/asymilacja na pograniczach kulturowych Europy Środkowo-Wschodniej $w$ XIX i XX wieku, t. 2: Sasiedztwo polsko-niemieckie, (Warszawa: Oficyna Wydawniczo-poligraficzna „Konika”, 2012).

Traba, Robert. „Procesy akulturacji/asymilacji w perspektywie badań historycznych. Przypadek pogranicza polsko-niemieckiego w XIX-XX wieku”, w: Robert Traba (red.), Akulturacja/asymilacja na pograniczach kulturowych Europy Środkowo-Wschodniej w XIX i XX wieku, t. 2: Sasiedztwo polsko-niemieckie, (Warszawa: Oficyna Wydawniczo-poligraficzna „Konika", 2012), 7-32. 
Tyrrell, Ian. „Reflections on the transnational turn in United States history: theory and practice", Journal of Global History, vol. 4, iss. 3, 2009, 453-474.

Urbański, Jarosław. Wiecowiczki, Zofia Tułodziecka i poczatki radykalnego zawodowego ruchu kobiecego w Wielkopolsce, (Poznań: Oficyna Wydawnicza Bractwo Trójki, 2018).

Walzer, Anke. Käthe Schirmacher. Eine deutsche Frauenrechtlerin auf dem Wege vom Liberalismus zum konservativen Nationalismus, (Pfeffenweiler: Centaurus-Verlagsgesellschaft, 1991).

Wawrzykowska-Wierciochowa, Dionizja. „O udziale Polek w międzynarodowym ruchu kobiecym”, Pamiętnikarstwo Polskie, nr 1-4, 1976, 59-72.

Werner, Michael. Zimmermann, Bénédicte. „Beyond Comparison: Histoire Croisée and the Challenge of Reflexivity", History and Theory, vol. 45, 2006, 30-50.

Werner, Michael. Zimmermann, Bénédicte. „Vergleich, Transfer, Verflechtung. Der Ansatz der Historie croisée und die Herausforderung des Transnationalen", Geschichte und Gesellschaft, Jg. 28, 2002, 607-636.

Wierzchosławski, Szczepan. Orzeł czarny i orzeł biały. Problemy modernizacji społeczeństwa polskiego prowincji Prusy Zachodnie w XIX i na poczatku XX stulecia, (Olsztyn: Littera, 2011).

Wolff, Kerstin. „Herrenmoral: Anna Pappritz and abolitionism in Germany”, Women's History Review, vol. 17, no. 2, 2008, 225-237.

Wyder, Grażyna. „Działalność edukacyjna kobiet - Polek w Wielkim Księstwie Poznańskim w drugiej połowie XIX wieku jako czynnik kształtowania świadomości narodowej”, Rocznik Lubuski, t. 35, cz. 1, 2009, 85-100.

Wyder, Grażyna. „Towarzystwo Pomocy Naukowej dla dziewcząt polskich w Wielkim Księstwie Poznańskim w latach 1871-1918”, w: Agnieszka Janiak-Jasińska, Katarzyna Sierakowska, Andrzej Szwarc (red.), Działaczki społeczne, feministki, obywatelki. Samoorganizowanie sie kobiet na ziemiach polskich do 1918 roku (na tle porównawczym), (Warszawa: Neriton, 2008), 307-321.

Wyder, Grażyna. „Wielkopolskie działaczki w ruchu narodowo-demokratycznym na terenie Poznańskiego na przełomie XIX i XX wieku. Szkic do działalności politycznej kobiet", Czasopismo Naukowe Instytutu Studiów Kobiecych, t. 1 (2), 2017, 48-72. 
Wyder, Grażyna. „Z dziejów walki o tożsamość narodowa - tajne stowarzyszenie kobiet "Warta»", w: Grażyna Wyder, Tomasz Nodzyński (red.), Polacy - Niemcy - Pogranicze. Studia Historyczne, (Zielona Góra: Oficyna Wydawnicza Uniwersytetu Zielonogórskiego, 2006), 183-200.

Zawiszewska, Agata. „Aktivitätsmodelle der deutschen Frauenbewegung um die Wende vom 19. zum 20. Jahrhundert in gesellschaftlicher und publizistischer Tätigkeit von Paulina Kuczalska-Reinschmit”, Colloquia Germanica Stetinensia, t. 25, 2016, 101-120. 